\title{
Pengaruh Kombinasi Pupuk NPK dengan Suplemen Pupuk Organik Cair terhadap Jumlah Bakteri dan Jamur Total di Rizosfer serta Hasil Tanaman Sawi Putih (Brassica pekinensis L.) pada Andisols Lembang
}

\author{
Dirga Sapta Sara, Reginawanti Hindersah, Mieke Rochimi Setiawati \\ Departemen Ilmu Tanah dan Sumberdaya Lahan Fakultas Pertanian Universitas Padjadjaran \\ Jl. Raya Bandung Sumedang Km 21, Jatinangor \\ Korespondensi: dirga.sapta@unpad.ac.id
}

\begin{abstract}
Large P fixation on Andisols can be overcome by adding P fertilizer into soil. However, to support good plant growth required the provision of nutrients $N, K$, micro nutrients and hormones. Research objective was to find out effect of NPK fertilizer with liquid organic fertilizer on total bacteria and fungi in the rhizosphere and plant yield of chinesse cabage (Brassica pekinensis L.) grown in Andisols. Experiment was conducted from March until May 2011 at experimental field of PT. Multiguna Indah Lestari, Kayu Ambon village, Lembang subdistrict, Bandung regency, West Java, with altitude of $1000 \mathrm{~m}$ above sea levels. The experimental design was Randomized Block Design with nine treatments and three replications which consisting of combination. The fertilizer rates were without treatment (A), 1dose of NPK (B), 1 dose of liquid organic fertilizer $(C), 1$ dose of NPK $+1 / 2$ dose of liquid organic fertilizer (D), 1 dose of NPK $+1 / 2$ dose of liquid organic fertilizer (E), $1 / 2$ dose of NPK +1 dose of liquid organic fertilizer $(F), 1 / 2$ dose of NPK +1 dose of liquid organic fertilizer (G), 1 dose of NPK +1 dose of liquid organic fertilizer $(H), 1$ dose of NPK $+11 / 2$ dose of liquid organic fertilizer (I). The results showed that NPK fertilizers and liquid organic fertilizer influenced total bacterial as well as fungi in the rhizosphere and plant yield of chinesse cabage. Fertilization treatments that demonstrated the best effect on both microbial population and chinese cabbage yield was application of $1 / 2$ recommended dose of NPK with 1 recomended dose of liquid organic fertilizer gives the best result of $54,72 \mathrm{~kg}$ per plot $\left(54,18\right.$ ton $\left.\mathrm{ha}^{-1}\right)$.
\end{abstract}

Keywords: chinesse cabage, liquid organic fertilizer, total bacteria, total fungi

\section{PENDAHULUAN}

Penyebaran Andisols di Indonesia mencapai 3,4 \% luas daratannya, atau diperkirakan mencapai 6.491.000 hektar. Daerah Jawa Barat sendiri luas Andisols sekitar 500.000 hektar (Munir, 1996). Salah satu daerah penyebaran Andisols di Jawa Barat terdapat di Lembang. Berdasarkan deskripsi profil tanah, Andisols Lembang di desa Kayu Ambon termasuk sub ordo Undands, great group Hapludands dan sub group Thaptic Hapludands. Tanah ini mempunyai $60 \%$ sifat tanah andik sampai kedalaman $60 \mathrm{~cm}$ dengan kadar C-organik $\geq 3$ $\%$, warna gelap (value $<3,5$ dan chroma $<3,5$ ) seperti epipedon molik (Fiantis, 2007).

Andisols Lembang pada penelitian ini mempunyai ketersediaan $P$ yang rendah yaitu 9,1 mg kg-1, meskipun P-potensial tinggi yaitu 42,55 $\mathrm{mg} \mathrm{kg}^{-1}$. Kondisi tersebut menunjukkan adanya fiksasi $\mathrm{P}$ yang menyebabkan $\mathrm{P}$ tidak dapat tersedia bagi tanaman, hal ini dapat mengakibatkan pertumbuhan tanaman terganggu. Menurut Cordova et. al. (1996), fiksasi fosfat pada Andisols menyebabkan P tidak tersedia bagi tanaman sehingga perlu aplikasi pemupukan.

Tanaman sayuran yang digunakan dalam penelitian ini adalah sawi putih (Brassica pekinensis L.) yang merupakan salah satu jenis sayuran yang banyak diusahakan di dataran tinggi khususnya Lembang. Syarat tanah yang ideal untuk tanaman sawi adalah subur, gembur, banyak mengandung bahan organik (humus), tidak tergenang, tata udara dalam tanah berjalan dengan baik, dan $\mathrm{pH}$ antara 6 - 7 (Mustovo et. al., 2017). Sawi putih dapat beradaptasi dengan baik di dataran tinggi dengan ketinggian lebih dari $1.000 \mathrm{~m}$ di atas permukaan laut. Sawi putih membutuhkan asupan unsur hara yang cukup untuk menunjang pertumbuhannya, tetapi Andisols memiliki ketersediaan $\mathrm{P}$ yang rendah, oleh karena itu dibutuhkan pemupukan agar sawi putih dapat tumbuh optimal. Pemupukan berdasarkan rekomendasi dari BALITSA untuk tanaman sawi putih yaitu sebanyak $100 \mathrm{~kg}$ ha1 Urea, 100 kg ha-1 SP-36, 75 kg ha-1 KCl. 
Pupuk anoganik pada kenyataannya dapat meningkatkan produksi pertanian, namun hal ini hanya berlangsung dalam jangka pendek, sedangkan dalam jangka panjang bahan-bahan tersebut dapat menurunkan produksi pertanian baik kuantitas maupun kualitas (Istarofah dan Salamah, 2017). Dampak penggunaan pupuk anorganik dapat dikurangi dengan pupuk organik, salah satunya yaitu dengan suplemen pupuk organik cair. Pupuk organik cair yang diaplikasikan melalui daun lebih cepat penyerapannya daripada pemupukan melalui tanah, karena pada permukaan daun terdapat banyak stomata (Febriana et. al, 2018).

Mikroorganisme sangat penting keberadaannya di rizosfer karena terlibat dalam siklus unsur hara, berperan sebagai penyedia unsur hara bagi tanaman, dan berperan dalam produktivitas tanaman. Pemupukan dapat mempengaruhi keberadaan mikroorganisme potensial di rizosfer dan selanjutnya siklus unsur hara di rizosfer. Aplikasi melalui daun dari pupuk organik cair mengakibatkan perubahan mikroorganisme di rizosfer dengan mengubah pola eksudat akar, yaitu tanaman akan lebih banyak mengeluarkan eksudat sebagai nutrisi bagi mikroorganisme tanah (Naihati et. al., 2018).

Penelitian efek kombinasi pupuk NPK dan pupuk organik cair terhadap produksi berbagai tanaman telah banyak dilakukan tetapi belum banyak yang meneliti terhadap jumlah bakteri dan jamur tanah total di rizosfer. Oleh karena itu penelitian ini penting dilakukan karena erat kaitannya mikroorganisme di dalam tanah dengan unsur hara maupun hasil produksi pertanian, termasuk pada tanaman sawi putih.

\section{BAHAN DAN METODE}

\subsection{Bahan dan Alat}

Bahan-bahan yang digunakan dalam penelitian ini adalah: (1) Pupuk organik cair berbahan dasar urin sapi sebanyak $235,5 \mathrm{~mL}$, (2) Pupuk Urea ( $45 \%$ N) sebanyak 1.320 gr, SP$36\left(36 \% \mathrm{P}_{2} \mathrm{O}_{5}\right)$ sebanyak $1.320 \mathrm{gr}$, dan $\mathrm{KCl}$ $\left(60 \% \mathrm{~K}_{2} \mathrm{O}\right)$ sebanyak $990 \mathrm{gr}$, (3) Benih tanaman sawi putih varietas Deli CR sebanyak 45 gr, (4) Pestisida Dursban 20 EC dan pestisida Prevathon 50 EC dan (5) Media tumbuh untuk analisis bakteri dan jamur.

Alat-alat yang digunakan dalam penelitian ini adalah: (1) peralatan laboratorium untuk analisis jumlah bakteri dan jumlah jamur, (2) peralatan pendukung yang digunakan dalam penelitian diantaranya: timbangan, plang nama, cangkul, dan alat tulis, (3) tempat pesemaian, (4) mulsa plastik perak hitam, (5) satu unit komputer sebagai alat untuk mengolah data.

\subsection{Rancangan Percobaan}

Penelitian ini menggunakan Rancangan Acak Kelompok (RAK) dengan satu faktor, yang terdiri atas 9 perlakuan yaitu:
A : tanpa perlakuan,
B : 1dosis NPK + tanpa POC,
C : tanpa NPK +1 dosis POC,
D : 1 dosis NPK $+1 / 2$ dosis POC
E : $1 / 2$ dosis NPK +1 dosis POC,
F : $3 / 4$ dosis NPK +1 dosis POC,
$\mathrm{G}: 1$ dosis NPK +1 dosis POC,
$\mathrm{H}: 1$ dosis NPK $+1 \frac{1}{2}$ dosis POC
I : $1 / 2$ dosis NPK $+1 \frac{1}{2}$ dosis POC

Masing-masing perlakuan diulang sebanyak tiga kali, sehingga terdapat 27 satuan percobaan. Satuan percobaan tersebut berupa petak percobaan berukuran 2 x 4 meter. Variabel respon yang diamati yaitu: jumlah bakteri dan jamur di rizosfer serta hasil tanaman sawi putih.

\subsection{Pengambilan Contoh Tanah}

Contoh tanah diambil bersamaan dengan masa panen yaitu 60 HST dengan cara mengambil tanah di daerah perakaran yang pengambilannya dilakukan secara komposit dengan menggabungkan tanah dari titik-titik contoh tanah yang dianggap mewakili dalam suatu petak percobaan. Contoh tanah rizosfer diambil dari lapisan tanah yang menempel di permukaan akar dengan menggunakan kuas setelah akar dikibaskan terlebih dahulu sampai tidak ada gumpalan tanah yang menempel di akar. 
Contoh pada setiap petak percobaan kemudian dibersihkan dari sisa-sisa tanaman yang selanjutnya tanah tersebut diaduk secara merata, kemudian dimasukkan ke dalam kantong plastik dan diberi label sesuai dengan perlakuannya masing-masing. Jumlah keseluruhan contoh tanah yang diambil dari tiap petak percobaan adalah 27 contoh dan dianalisis jumlah bakteri dan jamur di laboratorium.

\section{HASIL DAN PEMBAHASAN}

\subsection{Jumlah Bakteri dan Jamur di Rizosfer}

Pemberian pupuk NPK, POC maupun kombinasinya, meningkatkan jumlah bakteri dan jamur di rizosfer tanaman sawi putih saat panen (Tabel 1). Aplikasi NPK atau POC saja meningkatkan jumlah bakteri dibandingkan dengan control/Tanpa perlakuan, walaupun begitu pengaruh aplikasi kombinasi NPK dengan POC lebih meningkatkan jumlah bakteri di rizosfer.

Tabel 1 Pengaruh Kombinasi Pupuk NPK dengan Suplemen Pupuk Organik Cair terhadap Jumlah Bakteri Total di Rizosfer

\begin{tabular}{|c|c|}
\hline Perlakuan & $\begin{array}{c}\text { Jumlah } \\
\text { Bakteri } \\
\left(10^{10} \mathrm{CFU} \mathrm{g}^{-1}\right)\end{array}$ \\
\hline$\overline{\mathrm{A}}=$ Tanpa perlakuan (kontrol) & $2,18 \mathrm{a}$ \\
\hline $\mathrm{B}=1$ dosis NPK + tanpa POC & $2,90 \mathrm{~b}$ \\
\hline $\mathrm{C}=$ tanpa NPK +1 dosis POC & $3,18 \mathrm{bc}$ \\
\hline $\mathrm{D}=1$ dosis $\mathrm{NPK}+1 / 2$ dosis POC & $3,41 \mathrm{c}$ \\
\hline$E=1 / 2$ dosis NPK +1 dosis POC & $4,16 \mathrm{~d}$ \\
\hline$F=3 / 4$ dosis NPK +1 dosis POC & $4,40 \mathrm{de}$ \\
\hline$G=1$ dosis NPK +1 dosis POC & $4,41 \mathrm{de}$ \\
\hline $\mathrm{H}=1$ dosis NPK $+1 \frac{1}{2} 2$ dosis POC & $4,61 \mathrm{e}$ \\
\hline$I=1 / 2$ dosis NPK $+1 \frac{1}{2} 2$ dosis POC & $4,80 \mathrm{e}$ \\
\hline
\end{tabular}

Tabel 1 memperlihatkan bahwa kombinasi antara NPK dengan POC memberikan hasil jumlah bakteri yang lebih tinggi bila dibandingkan dengan perlakuan tunggal. Penelitian ini menunjukkan bahwa jumlah bakteri di rizosfer dengan pemberian kombinasi $1 / 4,1 / 2$, dan $3 / 4$ dosis pupuk NPK disertai dengan satu dosis POC tidak berbeda nyata. Perlakuan 1 dosis NPK +1 dosis POC dan 1 dosis NPK $+1 \frac{1}{2} 2$ dosis POC didapat jumlah bakteri terbaik tetapi nilai ini tidak berbeda nyata dengan $1 / 2$ dosis NPK +1 dosis POC dan $3 / 4$ dosis NPK +1 dosis POC, artinya untuk mendapatkan jumlah bakteri yang sama maka dengan perlakuan $1 / 2$ NPK dengan 1 POC merupakan perlakuan terbaik diantara perlakuan dalam menghasilkan jumlah bakteri di rizosfer. Bakteri rizosfer berperan penting dalam menyediakan unsur hara. Bakteri rizosfer mampu meningkatkan efisiensi pemupukan dan mampu menghasilkan fitohormon seperti auksin dan giberelin, siderofor, antibiotika, vitamin dan nonvitamin yang dapat membantu pertumbuhan tanaman (Tkacz et. al., 2017).

Aplikasi NPK atau POC saja juga meningkatkan jumlah jamur dibandingkan dengan kontrol/tanpa perlakuan (Tabel 2). Jumlah jamur di rizosfer lebih meningkat ketika diaplikasikan kombinasi NPK dengan POC. perlakuan $3 / 4$ dosis NPK +1 dosis POC memberikan hasil jumlah jamur yang tebaik bila dibandingkan dengan perlakuan Tanpa perlakuan (kontrol), NPK atau POC saja. Hal ini menunjukan bahwa dengan perlakuan kombinasi keduanya akan meningkatkan jumlah jamur di rizosfer. Perlakuan $1 / 2$ dosis NPK $+1 \frac{1}{2}$ dosis POC didapat jumlah jamur paling tinggi tetapi nilainya tidak berbeda nyata dengan perlakuan 1 dosis NPK +1 dosis POC dan 1 dosis NPK + $1 \frac{1}{2}$ dosis POC, artinya perlakuan $3 / 4$ NPK dan 1 POC merupakan perlakuan terbaik diantara perlakuan lainnya dalam menghasilkan jumlah jamur di rizosfer.

Kombinasi pupuk NPK dengan suplemen pupuk organik cair yang diberikan akan mendukung setiap fase pertumbuhan tanaman karena membantu menyediakan unsur hara baik makro ataupun mikro. Pemupukan menyebabkan pertumbuhan akar dan tajuk lebih intensif sehingga eksudat akar lebih banyak. Eksudat yang dikeluarkan akar merangsang mikroorganisme untuk berkumpul di perakaran tanaman dan bersimbiosis dengan tanaman tersebut. Seperti yang diungkapkan Lareen, et. al. (2016), bahwa akar 
tanaman juga membangun interaksi berupa simbiosis mutualisme dengan mikroorganisme membentuk asosiasi. Mikroorganisme menguntungkan yang berkoloni diperakaran dapat mensuplai unsur hara yang dibutuhkan oleh tanaman (Klaedtke et al., 2016). Simbiosis ini akan membantu cakupan akar dalam mendapatkan unsur hara.

Tabel 2 Pengaruh Kombinasi Pupuk NPK dengan Suplemen Pupuk Organik Cair terhadap Jumlah Jamur Total di Rizosfer

\begin{tabular}{lc}
\hline \multicolumn{1}{c}{ Perlakuan } & $\begin{array}{c}\text { Jumlah Jamur } \\
\left(10^{4} \mathrm{CFU} \mathrm{g}^{-1}\right)\end{array}$ \\
\hline $\mathrm{A}=$ Tanpa perlakuan (kontrol) & $1,65 \mathrm{a}$ \\
$\mathrm{B}=1$ dosis NPK + tanpa POC & $2,22 \mathrm{~b}$ \\
$\mathrm{C}=$ tanpa NPK +1 dosis POC & $2,53 \mathrm{c}$ \\
$\mathrm{D}=1$ dosis NPK $+1 / 2$ dosis POC & $2,70 \mathrm{~cd}$ \\
$\mathrm{E}=1 / 2$ dosis NPK +1 dosis POC & $2,95 \mathrm{de}$ \\
$\mathrm{F}=3 / 4$ dosis NPK + 1 dosis POC & $3,05 \mathrm{ef}$ \\
$\mathrm{G}=1$ dosis NPK +1 dosis POC & $3,20 \mathrm{efg}$ \\
$\mathrm{H}=1$ dosis NPK $+11 / 2$ dosis POC & $3,34 \mathrm{fg}$ \\
$\mathrm{I}=1 / 2$ dosis NPK $+11 / 2$ dosis POC & $3,37 \mathrm{~g}$ \\
\hline Keterangan: Angka-angka yang diikuti huruf yang \\
\multicolumn{2}{c}{ sama tidak berbeda nyata menurut uji } \\
jarak berganda Duncan $5 \%$
\end{tabular}

\subsection{Hasil Tanaman Sawi Putih}

Aplikasi pupuk organik cair maupun pupuk NPK meningkatkan hasil tanaman (Tabel 3). Produksi tanaman sawi putih terendah terdapat pada perlakuan Kontrol. Hasil tanaman sawi putih meningkat saat perlakuan NPK atau POC saja tetapi kombinasi kedua jenis pupuk lebih meningkatkan hasil. Pemberian 1/2, 3/4 dan 1 NPK disertai POC memberikan hasil panen yang secara statistik tidak berbeda satu dengan lainnya dan menghasilkan panen sawi putih yang tinggi dibandingkan perlakuan lainnya.

Hasil sawi putih yang berbeda nyata terdapat pada perlakuan $1 / 2$ dosis NPK +1 dosis POC, $3 / 4$ dosis NPK +1 POC, 1 dosis NPK +1 dosis POC dan 1 dosis NPK $+1 \frac{1}{2}$ dosis POC, menunjukkan hasil yang berbeda nyata. Dengan demikian, untuk mendapatkan hasil panen yang relatif sama, perlakuan $1 / 2 \mathrm{NPK}+1$ POC merupakan perlakuan yang paling efisien dalam meningkatkan hasil tanaman sawi putih menjadi $54,72 \mathrm{~kg}$ per petak atau setara dengan 58,14 ton ha $^{-1}$. Rata-rata produksi sawi putih hanya 40 ton ha ${ }^{-1}$, Hal ini menunjukkan bahwa kombinasi perlakuan $1 / 2$ dosis NPK +1 dosis POC dapat meningkatkan hasil sebesar 18,14 ton ha-1. Kombinasi pupuk NPK dengan pupuk organik cair dapat berpengaruh baik terhadap pertumbuhan tanaman karena pemupukannya yang berimbang antara pupuk NPK dengan pupuk organik cair dan dapat meningkatkan populasi mikroba yang dapat mendukung pertumbuhan tanaman (Chávez-Romero et. al, 2016).

Tabel 3 Pengaruh Kombinasi Pupuk NPK dengan Suplemen Pupuk Organik Cair terhadap Hasil Tanaman Sawi Putih dengan Faktor Koreksi 15 \%

\begin{tabular}{lcc}
\hline \multicolumn{1}{c}{ Perlakuan } & \multicolumn{2}{c}{ Hasil Tanaman } \\
\cline { 2 - 3 } & $(\mathrm{Kg} / \mathrm{petak})$ & $\left(\right.$ ton $\left.\mathrm{ha}^{-1}\right)$ \\
\hline $\mathrm{A}=$ Tanpa perlakuan (kontrol) & $30,84 \mathrm{a}$ & 32,72 \\
$\mathrm{~B}=1$ dosis NPK + tanpa POC & $33,91 \mathrm{~b}$ & 36,10 \\
$\mathrm{C}=$ tanpa NPK + 1 dosis POC & $38,72 \mathrm{~b}$ & 41,17 \\
$\mathrm{D}=1$ dosis NPK + $1 / 2$ dosis POC & $46.04 \mathrm{c}$ & 48,96 \\
$\mathrm{E}=1 / 4$ dosis NPK + 1 dosis POC & $49,33 \mathrm{c}$ & 52,36 \\
$\mathrm{~F}=1 / 2$ dosis NPK + 1 dosis POC & $49,33 \mathrm{c}$ & 52,36 \\
$\mathrm{G}=3 / 4$ dosis NPK + 1 POC & $54,72 \mathrm{~d}$ & 58,14 \\
$\mathrm{H}=1$ dosis NPK + 1 dosis POC & $56,77 \mathrm{~d}$ & 60,26 \\
$\mathrm{I}=1$ dosis NPK + 1 1 $1 / 2$ dosis POC & $57,12 \mathrm{~d}$ & 60,69 \\
\hline
\end{tabular}

Keterangan: Angka-angka yang diikuti huruf yang sama tidak berbeda nyata menurut uji jarak berganda Duncan $5 \%$

Pemupukan berimbang pada tanaman bertujuan untuk mencapai status semua unsur hara esensial yang seimbang dan sesuai kebutuhan tanaman agar tanaman dapat 
tumbuh optimal, meningkatkan produksi dan mutu hasil, meningkatkan efisiensi pemupukan, kesuburan tanah serta menghindari pencemaran lingkungan (Wei et. al., 2017). Aplikasi pupuk organik baik untuk daur ulang unsur hara tanah dan pengurangan pencemaran lingkungan dan pupuk anorganik baik untuk peningkatan hasil tanaman (Zhang et. al., 2017). Sifat pupuk anorganik dan pupuk organik menjadi strategi untuk pengelolaan unsur hara dan lingkungan perlindungan untuk tanah dibandingkan dengan hanya penerapan pupuk anorganik.

\section{KESIMPULAN}

Pemberian kombinasi pupuk NPK dengan suplemen pupuk organik cair berpengaruh dalam meningkatkan jumlah bakteri dan jamur total di rizosfer serta hasil tanaman sawi putih. Pemberian $1 / 2$ dosis NPK (Urea 50 gr per petak, SP-36 50 gr per petak, $\mathrm{KCl} 37,50$ gr per petak) dengan 1 dosis pupuk organik cair $(16 \mathrm{ml}$ per petak) memberikan hasil terbaik sebesar 54,72 kg per petak $\left(58,14\right.$ ton ha$\left.^{-1}\right)$.

\section{DAFTAR PUSTAKA}

Chávez-Romero, Y., Y. E. Navarro-Noya, S. C. Reynoso-Martínez, and Y. SarriaGuzmán. 2016. Metagenomics reveals changes in the soil bacterial community driven by soil organic $\mathrm{C}$, $\mathrm{N}$-fertilizer and tillage-crop residue management. J Soil Tillage Res. 159: 1-8.

Cordova, J., F. Valverde, and J. Espinosa. 1996. Phosphorus residual effect in Andisols cultivated with potatoes. Better Crops International. 10 (2): 6-8.

Febrianna, M., S. Prijono dan N. Kusumarini. 2018. Pemanfaatan pupuk organik cair untuk meningkatkan serapan nitrogen serta pertumbuhan dan produksi sawi (Brassica juncea L.) pada tanah berpasir. J Tanah dan Sumberdaya Lahan. 5(2): 109-118.

Fiantis, D. 2007. Morfologi dan Klasifikasi Tanah. Fakultas Pertanian Universitas. Andalas. Padang.
Istarofah, dan Z. Salamah. 2017. Pertumbuhan tanaman sawi hijau (Brassicae juncea L.) dengan pemberian kompos berbahan dasar daun paitan (Thitonia diversifolia). J Biosite 3(1), 39-46.

Klaedtke, S., M-A. Jacques, L. Raggi, A. Préveaux, S. Bonneau, V. Negri, V. Chable, and M. Barret. 2016. Terroir is a key driver of seed-associated microbial assemblages. J Environ Microbiol. 18(6): 1792-1804.

Lareen, A., F. Burton, and P. Schäfer. 2016. Plant root-microbe communication is shaping root microbiomes. J Plant Mol Biol. 90(6): 575-587.

Munir, M. M. 1996. Tanah-tanah Utama di Indonesia (Karakteristik, Klasifikasi, dan Pemanfaatannya). Pustaka Jaya, Malang.

Mustovo, H., Usman, dan F. Podesta. 2017. Pengaruh pemberian pupuk hijau pahitan dan kotoran sapi terhadap pertumbuhan dan hasil tanaman sawi pakcoy (Brassica rapa L.). J Agriculture. 11(4): 1393 - 1406.

Naihati, Y. F., R. I. C. O. Taolin, A. Rusae. 2018. Pengaruh takaran dan frekuensi aplikasi PGPR terhadap pertumbuhan dan hasil tanaman selada (Lactuca sativa L.). Savana Cendana Jurnal Pertanian Konservasi Lahan Kering. 3(1): 1 - 3.

Tkacz, A., J. Cheema, G. Chandra, A. Grant, and P. S. Poole. 2015. Stability and succession of the rhizosphere microbiota depends upon plant type and soil composition. The ISME Journal. 9: 2349-2359.

Wei, M., G. Hu, H. Wang, E. Bai, Y. Lou, \& A. Zhang. 2017. 35 years of manure and chemical fertilizer application alters soil microbial community composition in a Fluvo-aquic soil in Northern China. Eur. J. Soil Biol. 2017, 82: 27-34.

Zhang, X., Q. Zhang, B. Liang, \& J. Li. 2017. Changes in the abundance and structure of bacterial communities in the greenhouse tomato cultivation system under long-term fertilization treatments. J Appl Soil Ecol. 121: 82-89. 